\title{
A PHARMACOGNOSTICAL AND PHARMACOLOGICAL REVIEW ON BRYOPHYLLUM PINNATUM (PANPHUTI)
}

\author{
PASHA KHOOSHBU, IMTIYAZ ANSARI* \\ Department of Pharmacology, Oriental College of Pharmacy Sanpada, Navi Mumbai - 400 705, Maharashtra, India. \\ Email: imtiyaz.ocp@gmail.com
}

Received: 08 August 2018, Revised and Accepted: 06 September 2018

\begin{abstract}
Bryophyllum pinnatum is usually known as Panphuti which belong to family Crassulaceae growing widely in tropical Africa, tropical America, India, China, and Australia. It is a perennial herb grows 3-5 feet tall, fleshy dark green leaves that are distinctively scalloped and trimmed in red, and bell-like pendulous flowers. The plant contains various active compounds such as alkaloids, triterpenes, glycosides, flavonoids, steroids, bufadienolides, lipids, and organic acids. The pharmacological studies are reviewed and discussed, focusing on that different extracts from this plant have anti-inflammatory, antiallergic, antianaphylactic, antileishmanial, antitumorous, antiulcerous, antibacterial, gastroprotective, immunosuppressive, insecticidal, muscle relaxant, sedative, central nervous system depressant, and analgesic. Conventionally, it is used for the treatment of fever, constipation, nourishment of the hair and treating grey hair, intestinal disorder, and leucorrhea. The current review is created with an intended to focus on the numerous ethnobotanical and traditional use as well as the phytochemical and pharmacological report on $B$. pinnatum.
\end{abstract}

Keywords: Alkaloids, Bryophyllum pinnatum, Bufadienolides, Flavonoids, Hepatoprotective, Immunosuppressive, Phytoconstituents.

(C) 2019 The Authors. Published by Innovare Academic Sciences Pvt Ltd. This is an open access article under the CC BY license (http://creativecommons. org/licenses/by/4. 0/) DOI: http://dx.doi.org/10.22159/ajpcr.2019.v12i1.28988

\section{INTRODUCTION}

Medicinal plants have been known for times and are extremely respected worldwide as a rich home of helpful agents for the inhibition of diseases and illnesses [1]. Pan phuti plant native to Madagascar. This Wonder plant or Divine plant [2]. Leaf, stem, and root portions and its chemicals have great index in therapeutic [3]. It is a straight, juicy, continuing shrub that develops about $1.5 \mathrm{~m}$ tall and reappearances through spores and also vegetatively from leaf bubils. It has a towering deep stems, newly shady olive green leaves that are individually scalloped and pared in bloodshot and shady bell-like swinging floras. This plant can easily be broadcasted concluded stems or leaf harsh. It is an announced attractive plant that is nowadays mounting as a weed everywhere plantation produce [4]. In old-style remedy, Panphuti species have been used to give treatment for inflammation, infections, hypertension rheumatism, and cure of renal stones [5]. Phytochemicals can shield hominid from a variability of syndromes. Phytochemicals are non-nutritive plant mixtures, which ensure caring, medicinal, or illness defensive things. Plants produce these substances to save themselves; however, fresh examination determines that various phytochemicals can guard creatures beside syndromes. There are several phytochemicals in pods and sages and each mechanism contrarily [6]. In the modern years, pioneers are more fascinated to shrub beginning medications as they are greatly biocompatible with minor side effects than the man-made medications. The ordinary yield and class are not reasonable due to slow development degree, overexploitation, and environment demolition which are possibly the key drawbacks to see the ever-growing marketplace request. Additional farming of these rough therapeutically significant plants lacks satisfactory illness free Elite implanting resources due to great vulnerability of the crop for rhizome rot, leaf spot, and microbial wilt [7].

\section{SYNONYMS [8]}

Bryophyllum calycinum Salisb., Kalanchoe pinnata (Lam.) Pers., Cotyledon pinnata Lam., and Sedum madagascaricum Clus.

\section{COMMON NAME [9]}

Cathedral bells, curtain plant, floppers, good luck leaf, green mother of millions, leaf of life, Mexican love plant, miracle leaf, resurrection plant, and sprouting leaf.

\section{VERNACULAR NAME $[10,11]$}

Sanskrit: Parnabeeja, Asthibhaksha

English: Air plant

Hindi: Zakhmhaiyat, Pathharchoor

Kannada: Gandukalinga, Kadu basale

Malayalam: Elamarunga

Tamil: Malaikalli, Ranakalli

Telugu: Ranapala

Marathi: Gayamari

Bengali: Koppatha, Pathar kuchi.

\section{TAXONOMICAL CLASSIFICATION [12]}

Kingdom: Plantae - plants

Subkingdom: Tracheobionta - vascular plants

Division: Spermatophyta - seed plants

Subdivision: Magnoliophyta - flowering plants

Class: Magnoliopsida - dicotyledons

Subclass: Rosidae

Order: Rosales

Family: Crassulaceae - stonecrop

Genus: Bryophyllum

Species: B. pinnatum (Lam.) Oken.

\section{MACROSCOPY [13]}

Air plant is a pleasing glabrous herb $0.3-1.2 \mathrm{~m}$ tall. Twigs obtusely four slanting, mature one are bright colored and newer ones are roseate spotted with snowy. Leaves are mutable and decussate inferior is typically humble/complex, superior ones are 3-5/7 foliate with extended petioles. Petioles are combined by an edge nearby the 
stalk. Flyers are oval/elliptic with crenate/notch border. Floras are suspended, in big dispersion panicles with opposed divisions, pedicels willowy. Sepals are red striated, green at the immoral and pale green above. Petals are ruddy florid, puffy, and octagonal at the immoral, lobes three-cornered. Monofilaments green at the base, rose-pink lower the anthers. Anthers are hastate, shadowy. Flairs green. Fruitlet is enclosed in a insistent wispy calyx and corolla. Stones are lesser, oblong-ellipsoid, plane.

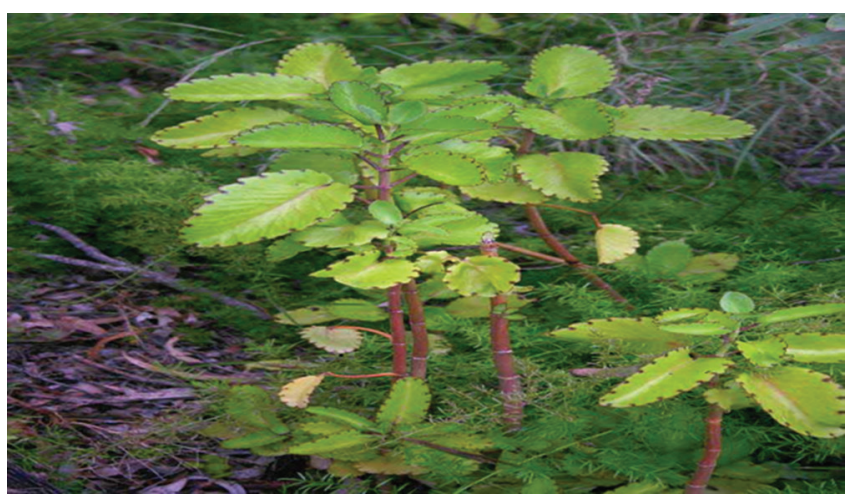

\section{MICROSCOPY [14]}

1. The tiny character displays a skinny sheet is existing on abaxial side and curved surface on the adaxial side. It has a shrill and adaxial epidermal film is of slight, less protuberant compartments. The stranded tissue of midrib is parenchymatous. The cells are round, pointed, and compressed.

2. The vascular strand is solitary, minor, and semicircular in form. It contains dense parallel orchestra of xylem and comprehensive band of phloem.

3. Xylem component is tapered, pointed, tinny wall. The vascular packs are in upright and parallel plane. The lamina is smooth, the mesophyll is discriminated into palisade and squishy parenchyma. The stomata are anisocytic type, which are established in rich form.

4. The longitudinal segment of greeneries shows occurrence of coiled vessels. The trichomes are lacking on abaxial cross and adaxial cross.

\section{PHYTOCHEMISTRY}

Introductory phytochemical examination of altered parts of plant mines of air plant displayed the occurrence of phenols alkaloids, , flavonoids, saponins, tannins, carotenoids, glycosides [15,16,17], sito sterol, anthocyanin,[18] malic acid, quinines, tocopherol[19], lectins [20,21],coumarins[22] and the key component are Bufadienolides-Bryophyllin A (bryotoxin)15; Bryophyllin B

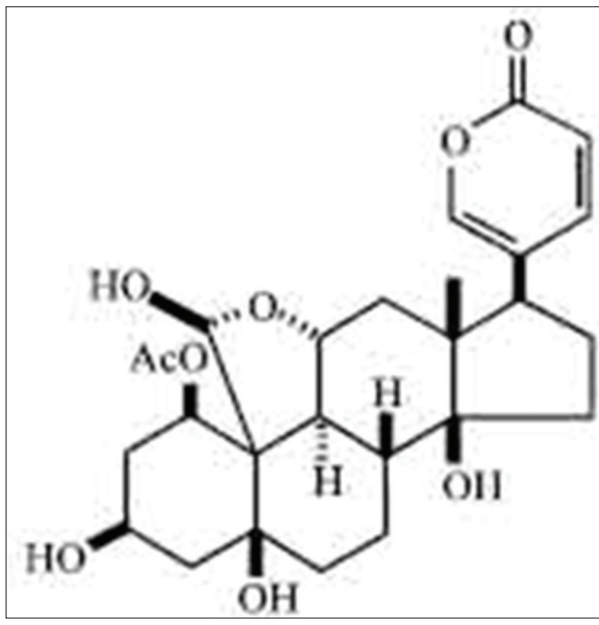

Fig. 1: Bryophyllin
(Fig.1); Bryophyllol (Fig.2); Bryophollone (Fig.3); Bryophollenone (Fig.4); Bryophynol (Fig.5) [23].The leaves are originate to hold several chemical constituents including 1-octane3-0- $\alpha$-Larabinopyranosyl-(1-6)-glucopyranoside [24,25], isorhamnetin-30-a-L-1C4-rhamnopyranoside, 40-methoxy-myricetin-3-0-a-L 1C4rhamnopyranoside and protocatechuic-40-0-b-D-4C1-glucopyranoside [26], 24-epiclerosterol [24(R)-stigmasta-5, 25-dien-3 $\beta$-ol], 24(R)-5 $\alpha$ stigmasta-7, 25-dien-3 $\beta$-ol, $5 \alpha$-stigmast-24-en- $3 \beta$-ol and 25 -methyl- $5 \alpha$ ergost-24 (28)-en-3 $\beta$-ol $[27,28]$. A new steroidal derivative, Stigmast-4, 20 (21), 23-trien-3-one was also isolated from the plant leaves extract along with stigmata-5-en-3 $\beta$-ol , $\alpha$ - amyrin- $\beta$-D-glucopyranoside, nundecanyl n-octadec-9-en-1-oate and n-dodecanyl noctadec-9-en1-oate [29]. Different naturally occurring flavanoids from leaves are flavones, falvans,flavanones,isoflavonoids, chalcones, aurones and

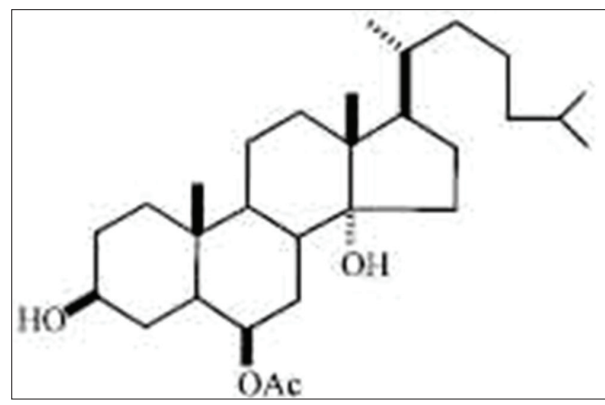

Fig. 2: Bryophyllol

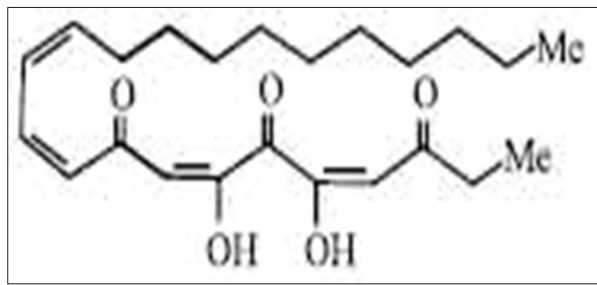

Fig. 3: Bryophollenone

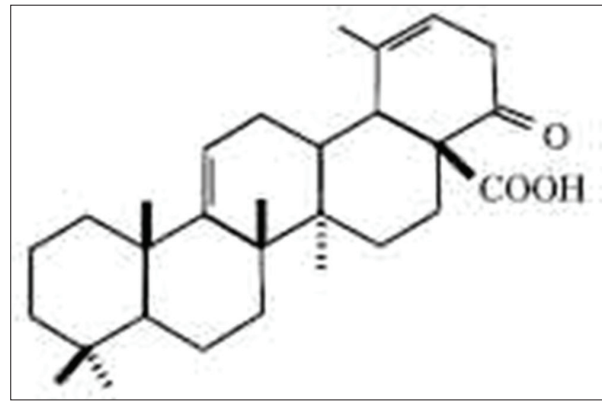

Fig. 4: Bryophollone

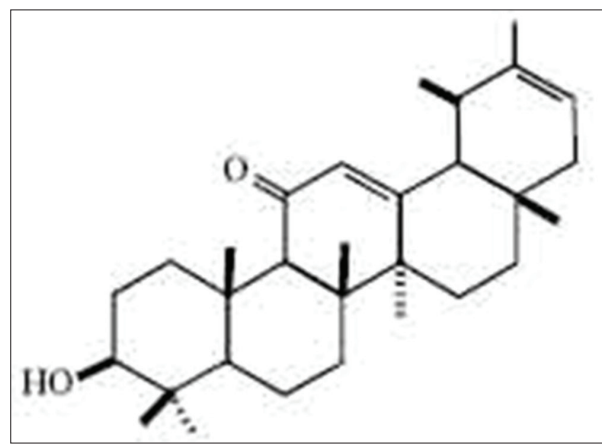

Fig. 5: Bryophynol 


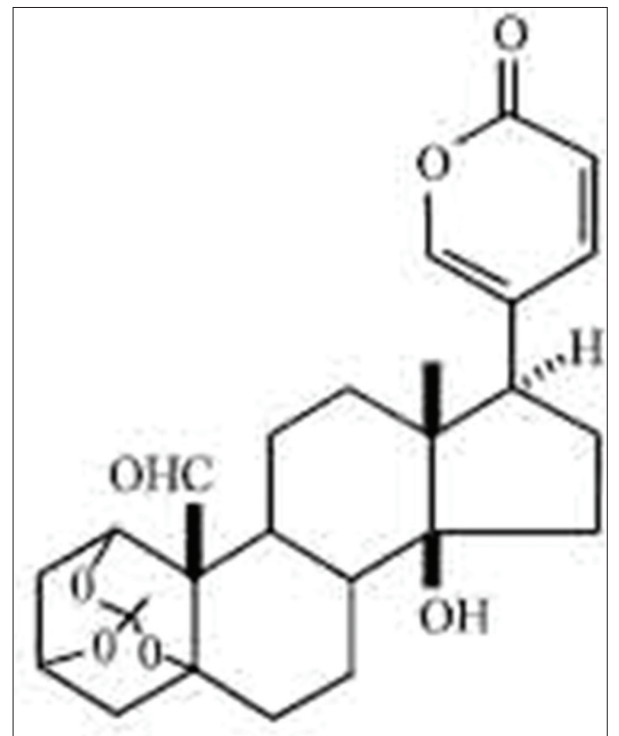

Fig. 6: Bersaldegenin

anthocyanidines[30,31.32],Compounds with potent biological activity are bersaldegenin- 1, 3, 5-orthoacetate [33] and bufadienolidebryophyllin B [34] and Bryophyllin C,.The main foundations, comprising calcium, phosphorus, sodium, potassium malate, magnesium and trace essentials (iron and zinc) were also firm in the plant extracts along with vitamins like ascorbic acid (26.42 to $44.03 \mathrm{mg} / 100 \mathrm{~g})$, riboflavin $(0.20$ to $0.42 \mathrm{mg} / 100 \mathrm{~g})$, thiamine $(0.11$ to $0.18 \mathrm{mg} / 100 \mathrm{~g})$, and niacin $(0.02$ to $0.09 \mathrm{mg} / 100 \mathrm{~g}$ ) casein hydrlylsate, nicotinamide[35,36,37].

\section{PHARMACOLOGICAL ACTIVITY}

\section{Wound healing property}

Patil et al. discovered the occurrence of wound curative action of Panphuti sheet. Removes from (petroleum ether, water, and alcohol) all the four abstracts, i.e., alcohol and waste petroleum ether displayed important upturn in the infringement power of opening wound when related to control group. Granuloma flouting strength and hydroxyproline contented of granulation tissue in deceased planetary wound model were meaningfully improved when associated to control group. Water quotation displayed major rise in wound shrinkage and development of marks on the $17^{\text {th }}$ post-wounding day in excision wound model. Uniform topical solicitation of aquatic extract speeded the curing procedure in removal wound model [38].

\section{ANTIULCER ACTIVITY}

Pal et al. showed that a methanolic fraction of leaves was established to retain important antiulcer activity. Premedication experiments in rats shown that the quotation possessed major shielding accomplishment in contradiction of the abdominal cuts tempted by aspirin, indomethacin, serotonin, reserpine, stress, and ethanol; also important shelter on behalf of aspirin-induced ulcer in pylorus-ligated rats and for histamine-induced gastric lesions in guinea pigs; and also significant improvement of the curing method was also establish to occur in acetic acid-induced chronic gastric lesions in rats [39]. Adesanwo et al. in his study showed a significant reduction in occurrence of ulceration and mean basal and histamine motivated gastrointestinal acid exudation in a dose reliant mode, therefore, modifying its apply as an antiulcer agent in tradition cure [40].

\section{UTERINE CONTRACTILITY}

Pathar kuchi improved shrinkage occurrence by $91 \%$ at constant amplitude and repressed oxytocin encouraged narrowing by $20 \%$ at continual breadth with faintly reduced regularity. Fenoterol reduced shriveling by $50 \%$ with an important reduction in rate [41]. Panphuti more operative and has fewer side effects than old-fashioned labor inhibitors in stopping preterm delivering. In a study Plangger et al. related the permissibility and tocolytic things among i.v., instilled plant abstract and beta-agonists. In a reflective study, 67 pairs of expectant females in preterm labor preserved with i.v. air plant or beta-agonists were carefully harmonized for motherly age, gestational age at tocolysis, cardiotocograph documented shrinkages, cervical effacement, preterm previous rupture of the skins, and past of preterm labor. Effects display that expecting women with quotation and beta-agonists were equivalent in the continuation of gestation ( 6.2 vs. 5.4 days, NS), the gestational stage at delivery ( 38.0 vs. 37.1 weeks, NS), and the time of hospitalizations but had less opposing things (34.3 vs. $55.2 \%$ with palpitation or dyspnea). The new consequence and injury in the B. pinnatum collection were equivalent or superior. Hence, established in the administration of preterm labor herb is no less operative than beta-agonists but is expressively improved accepted [42].

\section{HEPATOPROTECTIVE AND NEPHROPROTECTIVE}

Liquid of the new leaves is recycled very efficiently for the management of jaundice in Bundelkhand area of India. Yadav et al. planned that the liquid of greeneries was originate additional active than ethanolic excerpt as showed by in vivo and in vitro histopathological studies for hepatoprotective activity of herbal and validates the usage of liquid of plant leaves in folk drug for jaundice [43]. The protective effect on gentamicin-induced nephrotoxicity in rats which may involve its antioxidant and oxidative radical scavenging activities [44].

\section{NEUROPHARMACOLOGICAL}

Parnabeeja has been used since 1921 in predictable treatment as an antipsychotic mediator [45-47]. Salahdeen et al. showed that the aqueous leaf mine possesses depressant action on central nervous system (CNS). The animals CNS treat with $50-200 \mathrm{mg} / \mathrm{kg}$ was established to create rather important reduce in locomotor's movement in dose needy way, with no ptosis at these doses. Likewise in chimney, climbing and inclined screen tests, there was an important defeat of management and reduces muscle tone in animal treated intraperitoneally with aqueous extract in a dose reliant manner. The result indicates considerable alterations in universal behavior pattern, decrease in impulsive mortality, potentiation of pentobarbitoneinduced sleeping time in a dose needy manner $[48,49]$.

\section{IMMUNOSUPPRESSIVE}

The oily acids existing in Panphuti might be answerable at least in part, for its immunosuppressive result in vivo [50]. Rossi Bergmann et al. displayed the aqueous extract of grasses origin significant reserve of cell-mediated and humoral immune reactions in mice. The spleen cells of animals pre-treated with herbal abstract exhibited a compact capability to multiply in retort to equally mitogen and antigen in vitro. The in vitro and topical methods of direction were the most operative by nearly totally eliminating the Ddelayed-type hypersensitivity response. The intraperitoneal and verbal ways reduced the response by $73 \%-47 \%$ of controls, correspondingly. The exact antibody replies to ovalbumin were also meaningfully summary by handling. Thus, the aqueous extract of leaves keeps immunosuppressive activities. An effort to classify the immunosuppressive constituents presents in Panphuti directed by the lymphoproliferative assays. From the ethanolic abstract, a cleaned fraction (KP12SA) initiate 20 -fold added powerful to block murine lymphocyte explosion than the crude extract. Thus, the offers indication that saturated fatty acids present in basil shows significant character on lymphocyte propagation, which clarifies its immunosuppressive result in vivo [51].

\section{ANTIBACTERIAL}

The occurrence of phenolic component shows so as to the plant has antimicrobial action. Ofokansi et al. (2005) reported that plant is helpful in the management of typhoid fever and other bacterial infections, predominantly those caused by Bacillus subtilis, 
Staphylococcus aureus, Pseudomonas aeruginosa, Klebsiella aerogenes, Escherichia coli, Klebsiella pneumoniae, and Salmonella typhi. In his learn, antibacterial activities of the infusion and methanolic extracts against S. aureus American type culture collection (ATCC) 13709, E. coli ATCC 9637, Bacillus, P. aeruginosa, K. pneumonia, and S. typhi using the agar diffusion process; also adjacent to S. aureus, E. coli, S. typhi, Klebsiella spp., and P. aeruginosa using an alteration of examiner board way [52-54].

\section{ANTIDIABETIC, ANTI-INFLAMMATORY, AND ANTINOCEPTIVE ACTIVITY}

The occurrence of zinc in the vegetation could mean that the plants can play important roles in the management of diabetes, which outcome from insulin breakdown [55]. Ojewole evaluated the antinociceptive result of the herb's aqueous leaf mine by the "hot-plate" and "acetic acid" test models of pain in mice. The antidiabetic and antiinflammatory things of the plant extract were investigated in rats, using fresh egg albumin-induced pedal edema and streptozotocin-induced diabetes mellitus. The aqueous leaf extract created important $(\mathrm{p}<0.05-$ 0.001 ) antinociceptive effects adjacent to thermally and chemically induced nociceptive pain stimuli in mice. The plant takes out also appreciable inhibited fresh egg albumin-induced acute inflammation and causes important hypoglycemia in rats. The different polyphenols, triterpenoids and phytosterols, flavonoids, of the herb are speculated to account for the observed antinociceptive, anti-inflammatory, and antidiabetic properties of the plant. It exerts antinociceptive and antiinflammatory effects probably by inhibiting the release, synthesis, and/ or production of inflammatory cytokines and mediators, including prostaglandins, histamine, polypeptide kinins, and so on [56].

\section{HERBAL TONIC}

The plant is good sources of ascorbic acids, riboflavin, thiamine, and niacin. Natural ascorbic acid is vital for the body performance, i.e. normal formation of intercellular substances throughout the body, including collagen, bone matrix, and tooth dentine [57]. Therefore, the clinical manifestations of scurvy that is hemorrhage from mucous membrane of the mouth, gastrointestinal tract, anemia, and pains in the joints can be related to the association of ascorbic acid and normal connective tissue metabolism [58]. This function of ascorbic acid accounts for its normal wound healing property. As a result, the plant is used in herbal medicine for the treatment of common cold and other diseases like prostate cancer $[58,59]$. In a study, an herbal composition comprised extracts of number of herbs including B. pinnatum acts as a tonic to improve respiration, aids in the elimination of toxins, and improves overall vitality [60]

\section{PROTEIN PROFILING}

Phosphate extraction buffer ( $\mathrm{pH}$ ) was used to extract proteins from the leaves of B. pinnatum. On sodium dodecyl sulfate-polyacrylamide gel electrophoresis separation, the results showed that bands on the gel were then excised and digested with trypsin and subjected to liquid chromatography tandem mass spectrometry (MS/MS) for protein identification. Proteinase K has been identified from the MS/MS data. The protein identified was Proteinase K, which is used commercially in digesting of unwanted proteins like keratin [61].

\section{CYTOTOXICITY OF TESTIS}

The study revealed the cytotoxic effect of ethanolic extract of leaf of $B$. pinnatum on cells of rat's testis in two different doses $(100 \mathrm{mg} / \mathrm{kg}$ and $200 \mathrm{mg} / \mathrm{kg}$ ) orally for a period of 8 weeks. At the dose of $100 \mathrm{mg} / \mathrm{kg}$, the seminiferous tubules were shrunken and intracellular spaces were seen within the epithelium and higher dose $(200 \mathrm{mg} / \mathrm{kg})$ showed marked increase in intracellular spaces within the germinal epithelium and reduction of spermatozoa when compared with the control group which showed intact normal histological features of the testes [62].

\section{CYTOTOXIC TO CATTLE}

Mckenzie et al. investigated that cardiac glycoside poisoning was produced in calves given flower heads of the hybrid Bryophyllum species and found that for each plant (except B. tubiflorum), two calves were each given a single dose of $20 \mathrm{~g}$ wet weight per kg bodyweight. The results of the calf toxicity experiment with the amounts of bufadienolide measured in the plants suggest that bryotoxins A, B, and C probably account for the observed disease $[63,64]$

\section{INSECTICIDAL, FUNGITOXIC, AND PHYTOTOXIC ACTIVITY}

Alabi et al. studied to evaluate the fungitoxic and phytotoxic effects of extracts on the fungal pathogens inducing wilting on cowpea grown in Ago-Iwoye, Southwestern Nigeria. The extract reduces the disease infection rate in treated plants. Sclerotium rolfsii Sacc. induced wilting of between 4 and $12 \%$ on cowpea seedlings treated with plant extract under field conditions while about 39.6\% incidence of cowpea seedlings wilting was observed under control experiment on the same experimental plot. The extracts increased significantly the plant height, shelf life, relative water content, and chlorophyll contents of the cowpea seedlings during both the wet and dry season. On the other hand, the extracts significantly reduced transpiration rate and stomata aperture of treated plant in both seasons. Furthermore, application of these extracts on the cowpea plants significantly enhanced the leaf area index, number of branches and pods per plant, total dry matter per plant, weight per pod, 100 grains weight, and grain yield in both seasons. The extracts also inhibited the release of current photosynthethates from treated plants, thus maintaining the water status of plant and also making photosynthethates which can be oxidized to release energy needed for growth available to treated plants [65].

\section{OTHER ACTIVITY [66]}

- It is used against dysentery.

- B. pinnatum is used for the treatment of fever.

- Rhizome powdered is used for the treatment of constipation.

- B. pinnatum paste is used for the treatment of boil, wound, soar, or cuts.

- The extract of B. pinnatum is used for the treatment of roundworms (clotrimazole).

- The extract of the plant is used for the treatment of antipyretic activity.

- Using juice of this as eardrop heals the ear pain. Its natural remedy for ear pain.

- The paste of Pashanbheda mixed with honey is used for the beginners teething trouble.

- It is proved diuretic. Hence, it cures difficult urination.

- It is used as one of home remedies for piles (hemorrhoids).

- The leaf juice is used for the treatment of stomach ache.

- The extract is used for the nourishment of the hair and treating gray hair.

- The leaves are used against intestinal disorder.

- It is also used for the treatment of blood mixed diarrhea.

- The paste is used against leucorrhea.

- The fresh juice of Patharchur can be used to treat jaundice.

- It has importance in the treatment of certain types of cancer and weight management.

- It is the natural treatment for kidney and gallbladder stones.

\section{MARKETED PREPARATION [67]}

1. Amantol cream: Its indications are respiratory disorders, sinusitis, bronchitis, allergic reactions, and blocked nose. Ingredients are Mentha viridis extract (mint.), Iresine difusa (escanel) extract, Lippia alba extract (yantria), Zingiber officinalis extract (ginger), B. pinnata extract (Pakipanga), Mansia alliacea extract (ajode monte), mentol, alcanfor, and water cream base, external use only.

2. Parnabija savarasa: Antiobesity. 


\section{CONCLUSION}

B. pinnatum is very useful plant for treating various diseases such as wound healing, antiulcer, ant diabetic, anti-inflammatory, antinociceptive, and antibacterial, the chemical constituents flavonoid, alkaloid, saponin, and triterpenoid are responsible for this activity.

\section{ACKNOWLEDGMENT}

We are grateful to our Principal Dr. (Mrs.) Sudha Rathod and Dr. (Mrs.) Vanita Kanse for their guidance and support as well as to the Pharmacology Department, Oriental College of Pharmacy, Navi Mumbai, Maharashtra, India.

\section{AUTHORS' CONTRIBUTION}

We declare that this work was done by the authors named in this article and all liabilities pertaining to claims relating to the content of this article will be borne by the authors. Miss KHOOSHBU PASHA collected the data and analyzed the data. Prof. Imtiyaz Ansari proof-read the whole manuscript, and suggested the necessary changes, and helped in designing manuscript.

\section{CONFLICTS OF INTEREST}

The authors declare that there are no conflicts of interest regarding the publication of this paper.

\section{REFERENCES}

1. Sharma A, Shanker C, Tyagi LK, Singh M, Rao CV. Herbal medicine for market potential in India: An overview. Acad J Plant Sci 2008;1:26-36.

2. Kane SG. Extracts from Plant and Non-plant Biomass and Uses Thereof. US Application Publication, Publication No. US2004/0156920 A1; 2004. Available from: http://www.ip.com/patapp/US20040156920.

3. Simões-Wüst AP, Grãos M, Duarte $\mathrm{CB}$, Brenneisen R, Hamburger M, Mennet M, et al. Juice of Bryophyllum pinnatum (Lam.) inhibits oxytocin-induced increase of the intracellular calcium concentration in human myometrial cells. Phytomedicine 2010;17:980-6.

4. Biswas SK. Assesment of cytotoxicity and antibacterial activities of ethanolic extracts of Kalanchoe pinnata Linn. (Family: Crassulaceae) leaves and stem. Int J Pharm Sci Res 2011;2:2605-9.

5. Nayak BS, Marshall JR, Isitor G. Wound healing potential of ethanolic extract of Kalanchoe pinnata Lam. Leaf-A preliminary study. Indian J Exp Biol 2010;48:572-6.

6. Pathak D, Alam K, Rohilla H, Rai AR, Agrawal A. Phytochemical investigation of Boerhavia diffusa and Rograph paniculata: A comparative study. Int J Pharm Pharm Sci 2012;4:975-1491.

7. Mohanty S, Parida R, Sandeep IS, Sahoo S, Nayak S. Evaluation of drug yielding potential of micropropagated Curcuma aromatica. Int J Pharm Pharm Sci 2015;7:975-1491.

8. Available from: http://keyserver.lucidcentral.org/weeds/data/030308000b07-490a. [Last accessed on 2014 Sep 17].

9. Available from: http://www.keyserver.lucidcentral.org/weeds/ data/03030800-0b07-490a8d040605030c0f01/media/Html/ Bryophyllum_pinnatum.htm. [Last accessed on 2014 Sep 17].

10. Gurudeva MR. Botanical and Vernacular Names of South Indian Plants. Bangalore: Divya Chandra Prakashana; 2001. p. 245-246.

11. Chunekar KC, Pandey GS. In: Nighantu B, editor. Bhavamishra. Varanasi: Chaukhambha Bharathi Academy; 2010. p. 107.

12. Available from: http://www.somemagneticislandplants.com.au/index. php/plants/396-Bryophyllum-pinnatum. [Last accessed on 2014 Sep 17].

13. Kirthikar KR, Basu B. Indian Medicinal Plants Bryophyllum pinnatum (Lam.) Kurz (Crassulaceae). Allhebad: Lelitmohan Basu; 2002. p. $999-1000$

14. Khare CP. Encyclopedia of Indian Medicinal Plants. New York: Springer; 2004. p. 276

15. Kanika P. Pharmacognostic and phytochemical evaluation of Bryophyllum pinnatum leaves. J Adv Sci Res 2011;2;42-9.

16. Nguelefack TB, Nana P, Atsamo AD, Dimo T, Watcho P, Dongmo AB, et al. Analgesic and anticonvulsant effects of extracts from the leaves of Kalanchoe crenata (Andrews) haworth (Crassulaceae). J Ethnopharmacol 2006;106:70-5.

17. Okwu DE, Josiah C. Evaluation of the chemical composition of two Nigerian medicinal plants. Afr J Biotechnol 2006;5:357-61.

18. Nielsen AH, Olsen CE, Moller BL. Flavonoids inflowers of 16
Kalanchoe blossfeldiana varieties. Phytochemistry 2005:66:2829-35.

19. Pal S, Sen T, Chaudhari AK. Neuropsychopharmacological profile of the methanolic fraction of Bryophyllum Pinnatum leaf extract. J Pharm Pharm 1999;51:313-8.

20. Adinike K, Eretan OB. Purification and partial characterization of lectin from the fresh leaves of Kalanchoe crenata (And.) Haw. J Biochem Mol Biol2004;37:229-33.

21. Nguelefack TB, Nana P, Atsamo AD, Dimo T, Watcho P, Dongmo $\mathrm{AB}$, et al. Analgesic and anticonvulsant effects of extracts from the leaves of Kalanchoe crenata (Andrews) Haworth (Crassulaceae). J Ethnopharmacol 2006;106:70-5.

22. Liu KC, Yang SL, Roberts MF, Phillipson JD. Eupafolin rhamnosides from Kalanchoe gracilis. J Nat Prod 1989;52:970-4.

23. Misra S, Dixit S. Antifungal activity of leaf extract of some higher plants. Acta Bot Indica 1979;7:147-50.

24. Ram PR, Mehrotra BN. Compendium of Indian Medicinal Plants. New Delhi: Drug Research Institute; 2004

25. Quazi M, Sayyed N, Sheikh S, Gomase P, Choudhari A. Phytochemical analysis of chloroform extract of roots of Kalanchoe pinnata by HPLC and GCMS. Int J Pharm Sci Res 2011;2:1693-9.

26. von Mandac U, Plangger N, Rist L, Zimmermann R. Intravenous tocolysis with Bryophyllum pinnatum is better tolerated than betaagonis application. Eur J Obstet Gynecol Reprod Biol 2006;124:168.

27. Recknagael R. Carbontetrachloride hepatotoxicity. Pharm Rev 1967;19:145-96.

28 Almedia AP, Costa SS. Octane3-O- $\alpha$-larabinopyranosyl-(16)glucopyranoside, aminor constituent from leaves of Kalanchoe pinnata. Brazil J Pharm 2006;16:485-9.

29. Afzal M, Gupta G, Kazmi I, Rahman M, Afzal O, Alam J, et al. Antiinflammatory and analgesic potential of a novel steroidal derivative from Bryophyllum pinnatum. Fitoterapia 2012;83:853-8.

30. Amnlou M, Ariae S, Farsam H. J Med Aromat Plant Sci 2005;27:469-75.

31. Okwu DE, Nnamdi FU. Two novel flavonoids from Bryophyllum pinnatum and their antimicrobial activity. Pharm Chem J 2011;3:1-10.

32. Wagner WL, Herbst DR, Sohmer SH. Manual of the Flowering Plants of Hawaii. Honolulu: Universiy Hawaii Press; 1999. p. 568.

33. Yamagishi T, Haruna M, Yan XZ, Chang JJ, Lee KH. Antitumor agents 110, bryophyllin B, a novel potent cytotoxic bufadienolide from Bryophyllum pinnatum. J Nat Prod 1989;52:1071-9.

34. Morales AL, Sanchez CV, Jerkic M, Santiago JM, Gonzalez PD, Barriocanal FP. Effect of quercetin on metallothionein, nitric acid synthases and cycloooxygenase-2 expression on experimental chronic cadmium nephrotoxicity in rats. Toxicol Appl Pharm 2006;210:128-35.

35. Alabi DA, Onibudo MZ, Amusa NA. Chemicals and nutritional composition of four botanicals with fungitoxic properties. World $\mathrm{J}$ Agric Sci 2005;1:54-88.

36. Okwu DE, Josiah C. Evaluation of the chemical composition of two Nigerian medicinal plants. Afr J Biotechnol 2006;5:357-61.

37. Seema VP. Kalanchoe pinnata: Phytochemical and pharmacological profile. Int J Pharm Sci Res 2012;3:993-1000.

38. Patil PA, Shobha JC. Influence of Bryophyllum pinnatum (Lam.) leaf extract on wound healing in albino rats. J Nat Remedies 2004;4:41-6.

39. Pal S, Chaudhari AK. Studies on the anti-ulcer activity of a Bryophyllum pinnatum leaf extract in experimental animals. J Ethnopharmacol 1991;33:97-102

40. Adesanwo JK, Raji Y, Olaleye SB, Onasanwo SA, Fadare OO, Ige OO, et al. Antiulcer activity of methanolic extract of Bryophyllum pinnatum in rats. J Biol Sci 2017;7:409-412.

41. Gwehenberger B, Rist L, Huch R, von Mandach u. Effect of Bryophyllum pinnatum versus fenoterol on uterine contractility. Eur $\mathbf{J}$ Obstet Gynecol Reprod Bio1 2004;113:164-71.

42. Plangger N, Rist L, Zimmermann R, Mandach UV. Intravenous tocolysis with Bryophyllum pinnatum is better tolerated than betaagonist application. Eur J Obstet Gynecol Reprod Biol 2006;124:16872.

43. Yadav NP, Dixit VK. Hepatoprotective activity of leaves of Kalanchoe pinnata Pers. J Ethnopharm 2003;86:197-202.

44. Haslalka GV, Patil CR, Patil MR. Protective effect of Kalanchoe pinnata pers. (Crassulaceae) on gentamicin-induced nephrotoxicity in rats. Indian J Pharmacol 2007;39:201-5.

45. Pal S, Sen T, Nag AK. Neuropsychopharmacological profile of the methanolic fraction of Bryophyllum pinnatum leaf extract. J Pharm Pharm 1999;51:313-8.

46. Muzitano MF, Luzineide WT, Catherine G, Kaiser CR, Bergmann $\mathrm{BR}$, Costa CC. The antileishmanial activity assessment of unusual flavonoids from Kalanchoe pinnata. Phytochemistry 2006;67:2071-7. 
47. Rossi BR, Torres-Santos EC, Santos AP, Almeida AP, Costa SS, Da Silva SA. Treatment of cutaneous leishmaniasis with Kalachoe pinnata: Experimental and clinical data. Phytomedicine 2000;7:115

48. Fujimori H. Potentiation of barbital hypnosis as an evaluation method for CNS depressant. Psychopharmacology 1995;7:374-7.

49. Salahdeen HM, Yemitan OK. Neuropharmacological effects of aqueous leaf extract of Bryophyllum pinnatum in mice. Afr J Biomed Res 2006;9:101-7

50. Almeida AP, Da Silva SA, Souza ML, Lima LM, Rossi-Bergmann B, de Moraes VL, et al. Isolation and chemicals analisis of a fatty acid fraction of Kalanchoe pinnata with a potent lymphocyte suppressive activity. Planta Medica 2000;66:134-7.

51. Rossi-Bergmann B, Costa SS, Borges MB, da Silva SA, Noleto GR, Souza ML, et al. Immunosuppressive effect of the aqueous extract of Kalanchoe pinnata in mice. Phytothera Res 1994;8:399-402.

52. Okwu DE. Nigerian medicinal plant 11. Med Aromatic Plant Sci Biotechnol 2007;1:97-102.

53. Okwu DE. Evaluation of the chemical composition of indigenous spices of Southeastern Nigeria. Glob J Pure Appl Sci 2001;7:455-9.

54. Ofokansi KC, Esimone CO, Anele CK. Evaluation of the in vitro combined antibacterial effect of the leaf extracts of Bryophyllum pinnatum (Fam: Crassulaceae) and Ocimum gratissimum (Fam: Labiatae). Plant Prod Res J 2005;9:23-7.

55. Pal, Nag AK, Chaudhari N. Anti-inflammatory action of Bryophyllum pinnatum leaf extract. Fitoterapia 1990;61:527-33.

56. Ojewole JA. Antinociceptive, anti-inflammatory and antidiabetic effects of Bryophyllum pinnatum (Crassulaceae) leaf aqueous extract. J Ethno Pharm 2005;99:13-9.
57. Okwu DE, Okwu ME. Chemical composition of Spondia mombin (Linn) plant parts. J Sustain Agric Environ 2004;6:140-7.

58. Hunt, Groff IL, Holbrook J. Principles and Chemical Practice. New York: John Wiley and Sons; 1980. p. 459-62.

59. Okwu DE. Nigerian medicinal plant 11. Med Aromatic Plan Sci Biotechnol 2007;1:97-102.

60. Pal, Nag AK, Chaudhari N. Anti-inflammatory action of Bryophyllum pinnatum leaf extract. Fitoterapia 1990;61:527-33.

61. Sharma A, Bhot M, Chandra N. Protein profiling of Bryophyllum pinnatum (lam.) Kurz. leaf. Int J Pharm Pharm Sci 2014;6:496-7.

62. Akpantah AO, Obeten K, Edung ES, Eluwa AM. The effect of ethanolic extract of Bryophyllum pinnatum on the micro anatomy of the testes of adult males wister rats. Eur J Biol Med Sci Res 2014:2:37-44.

63. G. rappas Bryopyllum pinnatum Poisoning of Cattel. Aust Vet J 1995;72:425-7. Available from: http://www.findmeacure.com/2009/03/25/ kalanchoe-pinnata.

64. Reppas GP. Bryophyllum pinnatum poisoning of cattle. Aust Vet J 1995;72:425-7.

65. Alabi DA, Jimoh OA, Amusa NA. Fungitoxic and phytotoxic effect of Vernonia amygdalina (L), Bryophyllum pinnatum Kurz Ocimum gratissimum (Closium) L. and Eucalyptna globules (Caliptos) Labill water extracts on cowpea and cowpea seedling pathogens in Ago Iwoye, South Western Nigeria. World J Agric Sci 2005;1:70-5.

66. Available from: http://www.homeremediess.comMedicinal plants and their uses

67. Majaz QA, Tatiya AU, Khurshid M, Nazim S. The miracle plant (Kalanchoe pinnata): A photochemical and pharmacological review. Int J Res Ayurveda Pharm 2011;2:1478-82. 